\title{
Application of Mixture Design Using Diluted Acid for Extraction of Inorganic Components in Fruits of Casearia fasciculata and Determination by ICP OES: Evaluation by PCA and HCA
}

\author{
Ivana L. S. Romão, ${ }^{a, b}$ Franciele C. Novais, ${ }^{b}$ Rosivan S. Assis, ${ }^{b}$ Vinnícius H. C. da Silva, ${ }^{c}$ \\ Raildo M. de Jesus, ${ }^{c}$ Cleber G. Novaes ${ }^{\circledR} * b$ and Ana M. P. dos Santos ${ }^{a}$ \\ anstituto de Química, Universidade Federal da Bahia, Campus de Ondina, 40170-290 Salvador-BA, Brazil \\ ${ }^{\text {b} P r o g r a m a ~ d e ~ P o ́ s-G r a d u a c ̧ a ̃ o ~ e m ~ Q u i ́ m i c a, ~ D e p a r t a m e n t o ~ d e ~ C i e ̂ n c i a s ~ e ~ T e c n o l o g i a s, ~}$ \\ Universidade Estadual do Sudoeste da Bahia, 45208-091 Jequié-BA, Brazil \\ 'Departamento de Ciências Exatas e Tecnológicas, Universidade Estadual de Santa Cruz, \\ Campus Soane Nazaré, 45662-900 Ilhéus-BA, Brazil
}

\begin{abstract}
This study is the first to propose the simultaneous quantification of 10 elements in fruits of Casearia fasciculata by inductively coupled plasma optical emission spectrometry (ICP OES). A method of digestion using dilute nitric acid was optimized by mixture design for extraction of elements in the seed, peel, and pulp of Casearia fasciculata cultivated in the Bahia State, Northeastern Brazil. Four different approaches were used to evaluate the digestion procedure ((i) desirability; (ii) multiple response; (iii) residual carbon content and (iv) residual acidity). The accuracy of the method of digestion was applied for the extraction of the studied elements in two certified reference materials (RM-Agro E1001a Brachiaria brizantha and NIST 1515 apple leaves). The limits of quantification of the method $\left(\mu \mathrm{g} \mathrm{g}^{-1}\right)$ were: $\mathrm{Cr}, 0.42 ; \mathrm{Cu}, 0.69 ; \mathrm{Fe}, 1.5 ; \mathrm{Mn}, 0.14$; $\mathrm{Zn}, 1.8$; Ca, 29.0; K, 3.5; Mg, 1.9; P, 6.4; and S, 17. Two multivariate tools, principal component analysis (PCA) and hierarchical cluster analysis (HCA), were efficient in the formation of groups, corresponding to the fruit parts. Thus, the peel and seed of Casearia fasciculata present potential to be used as mineral supplements in human nutrition.
\end{abstract}

Keywords: elemental composition, Casearia fasciculata, ICP OES, PCA, HCA

\section{Introduction}

The characterization of food consumed by the population is an activity of extreme importance since, through the concentrations of the chemical components, it is possible to obtain information about food and nutritional security. Foods that present labels containing information about the composition end up having greater capacity of commercialization and acceptance by consumers. ${ }^{1}$ The lack of information about food is even more pronounced in regions of the Brazilian semi-arid region, especially in fruits of the Salicaceae family, which stands out for its economic and medicinal importance, besides presenting several attractive biological activities. ${ }^{2}$ The genus Casearia is included in the Salicaceae family, characterized by angiosperm plants, which comprises a total of 50 genera

*e-mail: cgalvaonovaes@gmail.com with about 1000 species found especially in tropical and subtropical regions. ${ }^{3}$ Species of this genus stand out for having biological activities such as anti-inflammatory, anti-ulcer, antivenom, cytotoxic, among others. ${ }^{4,5}$ However, there are few studies related to the quantification of inorganic components present in species of this genus.

The determination of low metal concentrations in food matrices requires the use of sufficiently sensitive and versatile techniques, and can be performed using a variety of analytical techniques such as laser-induced breakdown spectroscopy (LIBS), neutron activation analysis (NAA), microwave-induced plasma optical emission spectrometry (MIP OES), inductively coupled plasma optical emission spectrometry (ICP OES), inductively coupled plasma mass spectrometry (ICP-MS) and atomic absorption spectrometry (AAS). ${ }^{6}$ ICP OES has been widely used in different studies, ${ }^{7}$ since it provides good sensitivity, versatility, multi-element capacity, wide dynamic linear range, and high precision. 
Different methods that apply ICP OES as a multi-element technique use multiple response as a tool to establish an ideal experimental condition that is feasible for all analytes. Therefore, the global responses known as desirability (D) and multiple response (MR) are used. ${ }^{8}$

In general, before the sample is subjected to the analysis process, a dissolution, digestion or extraction step is necessary, yielding the analyte in solution form. ${ }^{9}$ The choice of the best procedure depends on the analyte to be determined and its concentration, the nature of the sample, the method of analysis and the desired accuracy. ${ }^{10,11}$

Many digestion methods use concentrated acids in the preparation of the sample. The presence of high acid concentrations may cause interference in the determination step and also increase the analytical blank values. An efficient and widely used alternative for sample digestion is the use of diluted acids, ${ }^{12}$ yielding some advantages to the method, such as: (i) reduction in reagent quantities and, consequently, reduction in blank values; and (ii) generation of solutions with lower acidity, especially when it comes to determination using fogging systems of the sample. ${ }^{11}$ Digestion methods using dilute nitric acid have shown great efficiency in the decomposition of several food matrices such as flax and sesame, ${ }^{13}$ rice,${ }^{14}$ tea leaves,${ }^{15}$ passion fruit, ${ }^{16}$ sports supplements, ${ }^{17}$ beans ${ }^{18}$ and milk powder. ${ }^{19}$

The efficiency of methods involving acid digestion can be assessed by residual acidity. Very acidic solutions can damage equipment accessories, reducing the useful life of the equipment. ${ }^{20}$ Residual carbon is another parameter to evaluate digestion efficiency in organic samples. Low residual carbon contents contribute to minimize interference, thus allowing good precision in the analyses, as well as avoiding variations in the surface tension and viscosity of the sample to be measured. ${ }^{21}$ Different sample digestion procedures can be optimized with the aid of multivariate techniques such as mixture design. ${ }^{22,23}$ These optimization techniques are particularly used in analytical chemistry in order to make a procedure more efficient and sensitive. $^{24}$

The purpose of this research was to develop a digestion procedure through the application of mixture design to optimize the components of a mixture (water, hydrogen peroxide and diluted nitric acid) for the digestion of different fruit tissues (seed, peel and pulp) of Casearia fasciculata. The design was evaluated through two general responses (desirability and multiple response) for ten elements, residual acidity and residual carbon content. Principal component analysis (PCA) and hierarchical cluster analysis (HCA) were used as statistical tools to evaluate the similarity of the different parts of the fruit investigated by ICP OES.

\section{Experimental}

\section{Instrumentation of ICP OES}

An ICP OES (Varian, model 710 ES, Melbourne, Australia) with axial configuration was used to quantify inorganic components in different fruit tissues. The ICP OES sample introduction system consisted of a concentric nebulizer OneNeb ${ }^{\circledast}$ (Agilent Technologies, Santa Clara, USA) and spray chamber cyclonic (Varian, Melbourne, Australia). The spectral emission lines (nm) were: $\mathrm{C}^{\mathrm{I}}, 193.027 ; \mathrm{Ca}^{\mathrm{I}}, 373.690 ; \mathrm{Cr}^{\mathrm{II}}, 267.716 ; \mathrm{Cu}^{\mathrm{I}}, 327.395$; $\mathrm{Fe}^{\mathrm{II}}$, 259.940; K , 766.491; $\mathrm{Mg}^{\mathrm{I}}$, 277.983; $\mathrm{Mn}^{\mathrm{II}}$, 257.610; $\mathrm{P}^{\mathrm{I}}, 213.618 ; \mathrm{S}^{\mathrm{I}}, 181.972$; and $\mathrm{Zn}^{\mathrm{I}}, 2$ 213.857. The analysis were performed at a radiofrequency power of $1400 \mathrm{~W}$, plasma argon flow rate of $15.0 \mathrm{~L} \mathrm{~min}^{-1}$, auxiliary argon flow rate of $1.5 \mathrm{~L} \mathrm{~min}^{-1}$ and nebulizer pressure of $200 \mathrm{kPa}$ following the operating conditions established by the manufacturer.

\section{Reagents and solutions}

All chemicals used in the analysis were of analytical grade. The solutions were all prepared using ultrapure water with resistivity of $18.2 \mathrm{M} \Omega \mathrm{cm}$ acquired from a Milli-Q purification system (Millipore, Bedford, MA, USA). Nitric acid solutions prepared by appropriate dilution of concentrated nitric acid (65\%, Synth, São Paulo, SP, Brazil) and hydrogen peroxide (30\%, Synth, São Paulo, Brazil) were used in the digestion step. Single-element $1000 \mathrm{mg} \mathrm{mL}^{-1}$ stock solutions (SigmaAldrich, St. Louis, USA) were used to prepare multi-element standard solutions. Carbon standard solutions were made from citric acid (PA, Vetec, Rio de Janeiro, Brazil). The residual acidity was determined using sodium hydroxide solution (PA, Vetec, Rio de Janeiro, Brazil) previously standardized with potassium biphthalate (PA, Biotec, Paraná, Brazil). All glassware was previously decontaminated by immersion in a $10 \%\left(\mathrm{v} \mathrm{v}^{-1}\right) \mathrm{HNO}_{3}$ solution for $24 \mathrm{~h}$.

\section{Optimization of sample digestion system}

A constrained mixture design was applied to optimize the volumes of ultrapure water, $30 \%$ hydrogen peroxide and $4.0 \mathrm{~mol} \mathrm{~L}^{-1}$ nitric acid employed in the digestion of the samples. The dehydrated fruit peel was used in the optimization study. Table 1 presents the experimental domain established and experimental matrix, performed randomly, and Figure 1 shows the delimited experimental region.

In order to establish an ideal condition to extract the ten analytes simultaneously, two multi-response approaches were used: desirability function (D) and multiple response 
Table 1. Design matrix and results of the mixture design for four responses

\begin{tabular}{|c|c|c|c|c|c|c|c|c|}
\hline \multicolumn{9}{|c|}{ Experimental domain } \\
\hline \multicolumn{2}{|l|}{ Variable } & \multicolumn{2}{|c|}{ Minimum } & \multicolumn{2}{|c|}{ Central point } & \multicolumn{2}{|c|}{ Maximum } & \\
\hline \multicolumn{2}{|c|}{ Ultrapure water / mL } & \multicolumn{2}{|c|}{3.0} & \multicolumn{2}{|c|}{4.0} & \multicolumn{2}{|c|}{5.0} & \\
\hline \multicolumn{2}{|c|}{$\mathrm{H}_{2} \mathrm{O}_{2}(30 \%) / \mathrm{mL}$} & \multicolumn{2}{|c|}{0.0} & \multicolumn{2}{|c|}{0.5} & \multicolumn{2}{|c|}{1.0} & \\
\hline \multicolumn{2}{|c|}{$\mathrm{HNO}_{3}\left(4.0 \mathrm{~mol} \mathrm{~L}^{-1}\right) / \mathrm{mL}$} & \multicolumn{2}{|c|}{1.0} & \multicolumn{2}{|c|}{1.5} & \multicolumn{2}{|c|}{2.0} & \\
\hline \multicolumn{9}{|c|}{ Experimental matrix } \\
\hline \multirow{3}{*}{ Run } & \multirow{3}{*}{$\mathrm{H}_{2} \mathrm{O}\left(\mathrm{X}_{1}\right) / \mathrm{mL}$} & \multirow{3}{*}{$\mathrm{H}_{2} \mathrm{O}_{2}\left(\mathrm{X}_{2}\right) / \mathrm{mL}$} & \multirow{3}{*}{$\mathrm{HNO}_{3}\left(\mathrm{X}_{3}\right) / \mathrm{mL}$} & \multicolumn{5}{|c|}{ Response } \\
\hline & & & & \multirow{2}{*}{$\mathrm{D}$} & \multirow{2}{*}{ MR } & \multirow{2}{*}{$\mathrm{RCC} / \%$} & \multicolumn{2}{|c|}{ Residual acidity } \\
\hline & & & & & & & $\left(\mathrm{mol} \mathrm{L}^{-1}\right)$ & $\%$ \\
\hline 1 & 5.0 & 0.0 & 1.0 & 0.46 & 8.34 & 7.44 & 0.19 & 1.36 \\
\hline 2 & 4.0 & 1.0 & 1.0 & 0.38 & 8.20 & 7.90 & 0.24 & 1.71 \\
\hline 3 & 4.0 & 0.0 & 2.0 & 0 & 7.38 & 4.72 & 0.03 & 0.21 \\
\hline 4 & 3.0 & 1.0 & 2.0 & 0.35 & 8.05 & 4.48 & 0.03 & 0.21 \\
\hline 5 & 4.5 & 0.0 & 1.5 & 0.38 & 8.18 & 4.86 & 0.03 & 0.21 \\
\hline 6 & 3.5 & 1.0 & 1.5 & 0.21 & 7.79 & 4.84 & 0.03 & 0.21 \\
\hline 7 & 4.5 & 0.5 & 1.0 & 0.33 & 7.98 & 8.49 & 0.03 & 0.21 \\
\hline 8 & 3.5 & 0.5 & 2.0 & 0.42 & 8.61 & 5.27 & 0.03 & 0.21 \\
\hline $9.1(\mathrm{CP})$ & 4.0 & 0.5 & 1.5 & 0.81 & 9.16 & 7.92 & 0.04 & 0.28 \\
\hline $9.2(\mathrm{CP})$ & 4.0 & 0.5 & 1.5 & 0.35 & 8.15 & 9.67 & 0.04 & 0.28 \\
\hline $9.3(\mathrm{CP})$ & 4.0 & 0.5 & 1.5 & 0.32 & 8.46 & 6.02 & 0.03 & 0.21 \\
\hline $9.4(\mathrm{CP})$ & 4.0 & 0.5 & 1.5 & 0.52 & 8.84 & 6.13 & 0.03 & 0.21 \\
\hline
\end{tabular}

D: desirability function; MR: multiple response function; RCC: residual carbon content; $\mathrm{CP}$ : central point.

function (MR) (Table 1). D was calculated combining the individual desirability $\left(\mathrm{d}_{\mathrm{i}}\right)$ values, according to equations 1 and $2 .{ }^{25}$ The individual desirability ranges between 0 and 1 .

$\mathrm{di}=\left\{\begin{array}{l}0, \text { if } \mathrm{y}<\mathrm{L} \\ \left(\frac{\mathrm{y}-\mathrm{L}}{\mathrm{T}-\mathrm{L}}\right), \text { if } \mathrm{L} \leq \mathrm{y} \leq \mathrm{T} \\ 1, \text { if } \mathrm{y}>\mathrm{T}\end{array}\right.$

$\mathrm{D}=\sqrt[\mathrm{n}]{\mathrm{di}_{1} \times \mathrm{di}_{2} \times \mathrm{di}_{3} \cdots \mathrm{di}_{\mathrm{n}}}$

where $y$ is the value of intensity for each element, $\mathrm{L}$ is the lowest value of intensity found in a series of experimental trials for each analyte and $\mathrm{T}$ is the highest value of intensity for each analyte.

The MR function was calculated according to equation 3 :

$\mathrm{MR}=\left[\frac{\mathrm{Int}_{\mathrm{Ca}}}{\operatorname{Int} \mathrm{m}_{\text {max.Ca }}}+\frac{\operatorname{Int}_{\mathrm{Cr}}}{\operatorname{Int}_{\text {max.Cr}}}+\cdots+\frac{\mathrm{Int}_{\mathrm{Zn}}}{\mathrm{Int}_{\max . \mathrm{Zn}}}\right]$

where Int is the intensity of emission of the analyte in an experiment and $\mathrm{Int}_{\max }$ is the larger signal obtained in a series of experimental trials. ${ }^{8}$

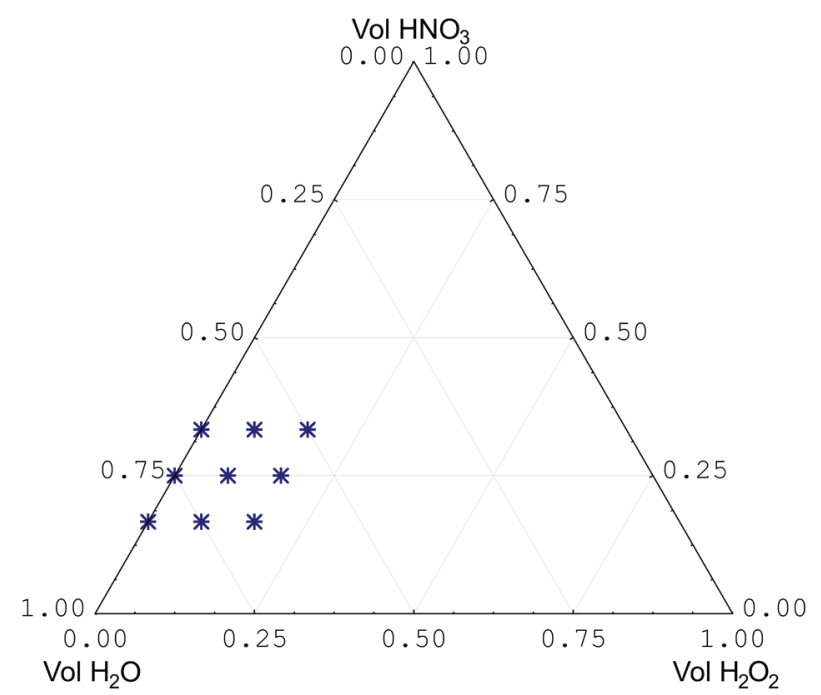

Figure 1. Experimental region of the constrained mixture design.

Residual carbon content (RCC) and residual acidity of the digested were also used as responses to evaluate the digestion efficiency (Table 1). RCC was assessed using citric acid standard solutions, monitored at $C^{\mathrm{I}} 193.025 \mathrm{~nm}$. A standardized solution of $0.1052 \mathrm{~mol} \mathrm{~L}^{-1}$ sodium hydroxide was used to measure the residual acidity by neutralization titration of $100 \mu \mathrm{L}$ of final digested. 


\section{Sample collection}

The fruits of Casearia fasciculata were collected in the summer of 2016, 2018 and 2019 in two regions (Bela Vista: latitude $13^{\circ} 37^{\prime} 12^{\prime}$ 'S and longitude $40^{\circ} 13^{\prime} 27^{\prime \prime} \mathrm{W}$; and Morro: latitude $13^{\circ} 36^{\prime} 09^{\prime}$ 'S and longitude 40¹4'13'”W), municipality of Lafaiete Coutinho, Southwest of Bahia, Brazil. After sampling, the samples were sent to the laboratory to perform the digestion process. Exsiccates were prepared for confirmation of the species and stored in the Herbarium (code HUESB 11664) of the State University of Southwest Bahia.

\section{Sample digestion}

Initially, the samples were cleaned and separated into pulp, peel, and seed. Peel and seed were dried for $12 \mathrm{~h}$ at $80{ }^{\circ} \mathrm{C}$ following an established procedure. ${ }^{16}$ The dried samples were then crushed for later digestion. The digestion of the pulp was performed without the need of drying step. About $0.2000 \mathrm{~g}$ of sample was weighed in polytetrafluoroethylene (PTFE) cups (23 mL). Nitric acid solution (4.0 mol L $\left.{ }^{-1}\right)$ and $30 \%$ hydrogen peroxide $(0.5 \mathrm{~mL})$ was then added in sequence to each digestion vessel (in triplicate). The mixture was heated in an oven at $160 \pm 10{ }^{\circ} \mathrm{C}$ for $4 \mathrm{~h} .{ }^{11}$ The final solutions were cooled, transferred to a $10 \mathrm{~mL}$ volumetric flask, filled with ultrapure water, and analyzed by ICP OES. Blank solutions were prepared similarly. The same treatment was applied for certified reference materials (RM-Agro E1001a Brachiaria brizantha cv. Marandu and NIST 1515 apple leaves).

\section{Statistical analysis}

Two multivariate tools for multielement data processing (PCA and HCA) were used for the treatment of the data obtained from the simultaneous determination of 10 analytes in 18 samples. Experimental data were analyzed by using the softwares Statistica ${ }^{26}$ and SPSS statistics $24 .{ }^{27}$

\section{Results and Discussion}

\section{Optimization of the sample digestion method}

Different sample digestion methods can be optimized using mixture design techniques. ${ }^{28}$ These techniques are widely used in order to improve the performance of a procedure or a method in order to make it more efficient and reliable for the extraction of analytes in several matrices. The analytical response obtained is dependent on the proportions of each component. ${ }^{24}$
In this study, a mixture design with restrictions was applied, involving three variables: ultrapure water volume $\left(\mathrm{X}_{1}\right)$, volume of $30 \%$ peroxide $\left(\mathrm{X}_{2}\right)$ and volume of $4.0 \mathrm{~mol} \mathrm{~L}^{-1}$ nitric acid $\left(\mathrm{X}_{3}\right)$. Four different approaches were used to evaluate the digestion procedure, at a confidence level of 95\%: (i) D; (ii) MR; (iii) RCC and (iv) residual acidity. For the global responses using the $\mathrm{D}$ and $\mathrm{MR}$ functions, the normalized emission intensities of the elements $\mathrm{Ca}, \mathrm{Cr}, \mathrm{Cu}, \mathrm{Fe}, \mathrm{Mn}, \mathrm{K}, \mathrm{Mg}, \mathrm{P}, \mathrm{S}$, and $\mathrm{Zn}$ were used. The variables, the applied experimental domain, and the four responses are shown in Table 1.

The response surfaces obtained by applying the mixture design are shown in Figure 2. Figure 2a presents the results using the D function as a response. This surface has a critical point represented by maximum point and, therefore, the coordinates of that point are the adequate proportions to obtain a greater response. Critical points are obtained by applying the Lagrange criterion, which is based on the Hessian determinant. ${ }^{29}$

Figure $2 \mathrm{~b}$ shows the results using the MR function. As in Figure $2 \mathrm{a}$, this surface also revealed a peak as a critical point. The quadratic model obtained for both global responses (D and MR) presented surfaces very similar regarding the visual aspect and optimal conditions, as can be observed in Figures $2 \mathrm{a}$ and $2 \mathrm{~b}$. The critical values found for the variables studied were also close and presented values within the studied experimental domain, as shown in Table 2.

In procedures involving the digestion of organic samples, the residual carbon content is a relevant parameter to be evaluated. Low RCC values in organic digests contribute to reduce spectral interferences from the residual carbon and to improve analysis accuracy. ${ }^{30}$

In this study, the maximum point obtained by the RCC evaluation is characterized as a saddle condition, that is, an intersection region between a relative minimum and a relative maximum. ${ }^{29}$ The coordinates of the saddle point do not present ideal conditions for the studied system and the critical values for one or more variables may be comprised outside the delimited experimental domain. Thus, a visual analysis of the surface in Figure $2 \mathrm{c}$ should be performed in order to find the ideal conditions.

Although a saddle condition appeared, the results obtained in all the experiments (Table 1) showed RCC values lower than $10 \%$, considered efficient for digestion procedures. The results are consistent with other studies published previously. ${ }^{18,31,32}$

Another parameter widely used to evaluate efficiency in digestion procedures is residual acidity. In spectrometric techniques such as ICP OES, it is advisable to introduce solutions with acidity lower than $10 \% \mathrm{v} \mathrm{v}^{-1}$ to avoid 

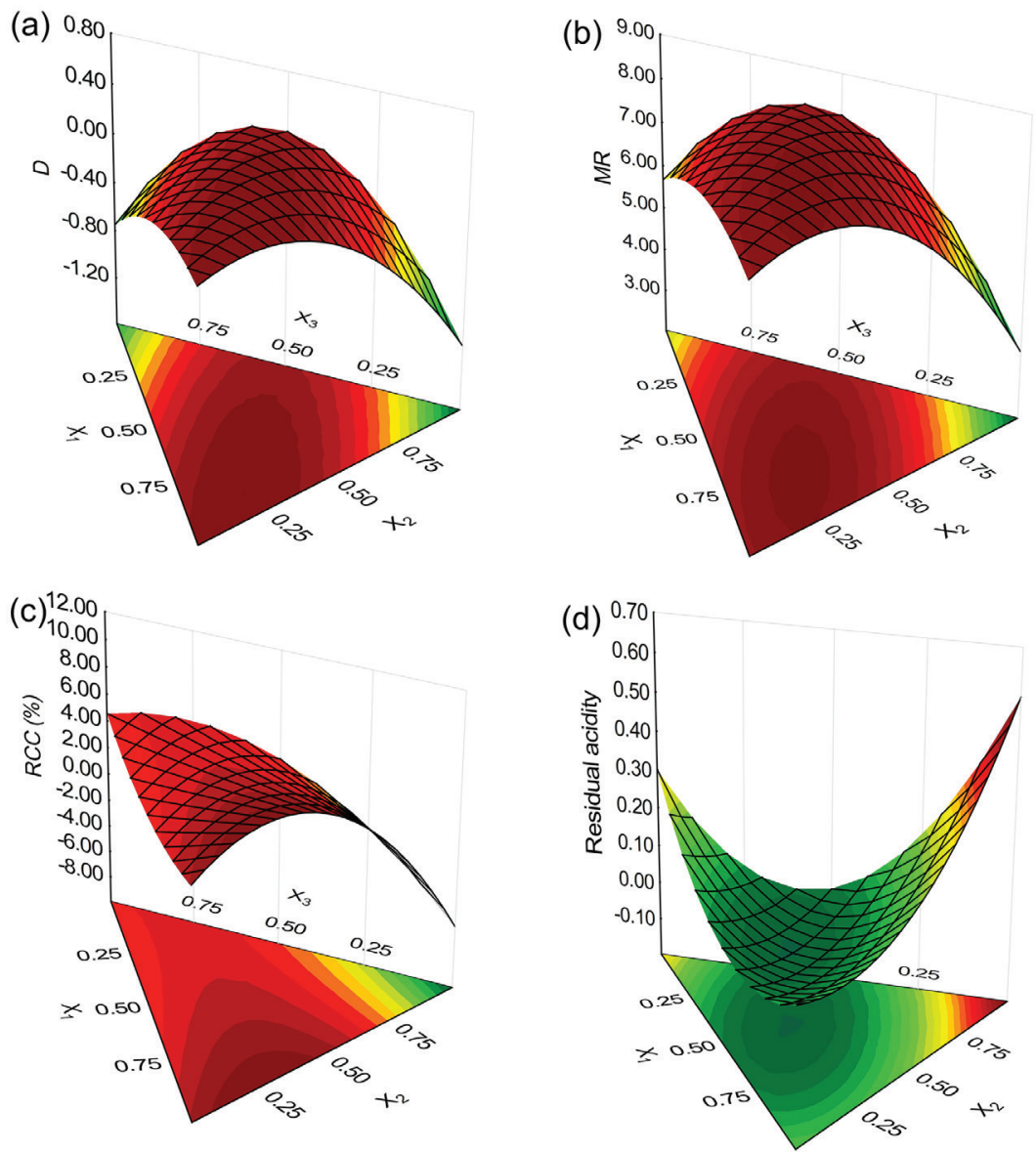

Figure 2. Response surfaces obtained from the mixture design to the (a) desirability; (b) multiple response; (c) residual carbon content and (d) residual acidity.

Table 2. Critical values obtained for mixture design using different responses

\begin{tabular}{lccccc}
\hline \multirow{2}{*}{ Variable } & Experimental domain & \multicolumn{3}{c}{ Response } \\
\cline { 3 - 6 } & & $\mathrm{D}$ & MR & RCC & Residual acidity \\
\hline Vol. $\mathrm{H}_{2} \mathrm{O}$ & $3.0-5.0$ & 4.48 & 4.13 & 2.99 & 3.64 \\
Vol. $\mathrm{H}_{2} \mathrm{O}_{2}$ & $0-1.0$ & 0.39 & 0.49 & 0.44 & 0.50 \\
Vol. $\mathrm{HNO}_{3}$ & $1.0-2.0$ & 1.13 & 1.38 & 2.56 & 1.86 \\
Solution & & maximun & maximun & saddlepoint & minimum \\
Lack of fit & & 0.0792 & 0.699 & 2.270 & $0.0179^{\mathrm{a}}$ \\
\hline
\end{tabular}

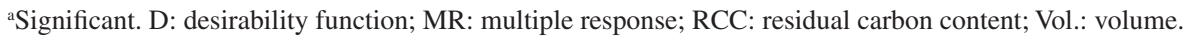

changes in aerosol transport during sample introduction. ${ }^{33}$ Results obtained using intermediate conditions (central point), within the delimited experimental domain, allowed excellent residual acidity conditions. The efficiency obtained using dilute acid can be explained by the ability of acid to regenerate in the presence of oxygen from the peroxide. ${ }^{34}$

Figure $2 \mathrm{~d}$ shows the results using residual acidity as a response. This surface has a minimum point as the critical point and, therefore, their coordinates are the ideal proportions to obtain a lower residual acidity. It is observed that the response surfaces (Figures $2 \mathrm{c}$ and $2 \mathrm{~d}$ ) show an inverse behavior. Thus, it is to be expected that, by increasing the proportion of $\mathrm{HNO}_{3}$, the residual acidity is increased, while the RCC is decreased.

The critical points of all the surfaces generated in Figure 2, considering the four responses, were obtained by solving a system of equations using the first derivative of the following equations. ${ }^{35}$ Values identified with $*$ are considered significant. 
$\mathrm{D}=+* 0.4337\left(\mathrm{VH}_{2} \mathrm{O}\right)-1.059\left(\mathrm{VHNO}_{3}\right)-$

$0.7529\left(\mathrm{VH}_{2} \mathrm{O}_{2}\right)+2.260\left(\mathrm{VH}_{2} \mathrm{O}\right)\left(\mathrm{VHNO}_{3}\right)+$

$0.9799\left(\mathrm{VH}_{2} \mathrm{O}\right)\left(\mathrm{VH}_{2} \mathrm{O}_{2}\right)+4.960\left(\mathrm{VHNO}_{3}\right)\left(\mathrm{VH}_{2} \mathrm{O}_{2}\right)$

$\mathrm{MR}=+* 8.191\left(\mathrm{VH}_{2} \mathrm{O}\right)+3.594\left(\mathrm{VHNO}_{3}\right)+$

$5.661\left(\mathrm{VH}_{2} \mathrm{O}_{2}\right)+7.760\left(\mathrm{VH}_{2} \mathrm{O}\right)\left(\mathrm{VHNO}_{3}\right)+$

$2.799\left(\mathrm{VH}_{2} \mathrm{O}\right)\left(\mathrm{VH}_{2} \mathrm{O}_{2}\right)+* 13.80\left(\mathrm{VHNO}_{3}\right)\left(\mathrm{VH}_{2} \mathrm{O}_{2}\right)$

$\mathrm{RCC}=+* 7.18\left(\mathrm{VH}_{2} \mathrm{O}\right)-5.306\left(\mathrm{VHNO}_{3}\right)+$

$4.559\left(\mathrm{VH}_{2} \mathrm{O}_{2}\right)+26.64\left(\mathrm{VH}_{2} \mathrm{O}\right)\left(\mathrm{VHNO}_{3}\right)-5.84\left(\mathrm{VH}_{2} \mathrm{O}\right)$

$\left(\mathrm{VH}_{2} \mathrm{O}_{2}\right)+18.0\left(\mathrm{VHNO}_{3}\right)\left(\mathrm{VH}_{2} \mathrm{O}_{2}\right)$

Residual acidity $=+* 0.1471\left(\mathrm{VH}_{2} \mathrm{O}\right)+0.5804\left(\mathrm{VHNO}_{3}\right)$ $+0.3004\left(\mathrm{VH}_{2} \mathrm{O}_{2}\right)-0.7\left(\mathrm{VH}_{2} \mathrm{O}\right)\left(\mathrm{VHNO}_{3}\right)-0.7\left(\mathrm{VH}_{2} \mathrm{O}\right)$ $\left(\mathrm{VH}_{2} \mathrm{O}_{2}\right)-1.6\left(\mathrm{VHNO}_{3}\right)\left(\mathrm{VH}_{2} \mathrm{O}_{2}\right)$

In the equations for the four responses evaluated, the $\mathrm{VH}_{2} \mathrm{O}$ was the only significant variable, and with a positive trend. This suggests that in more dilute conditions, the digestion is favored within the studied experimental domain. The variables $\mathrm{VH}_{2} \mathrm{O}_{2}$ and $\mathrm{VHNO}_{3}$, as well as the interactions between all the variables, were not significant in the process. The equations presented a good similarity and complete coherence for the variables and their interactions found by the response differents.

An ideal condition satisfying both the increase in emission signals and the reduction in residual acidity and residual carbon can be obtained by using intermediate volumes of the reagents used. Therefore, an efficient condition that simultaneously meets both trends corresponds to the following volumes: 4.0, 1.5 and $0.5 \mathrm{~mL}$ for $\mathrm{H}_{2} \mathrm{O}$, $\mathrm{HNO}_{3}$ and $\mathrm{H}_{2} \mathrm{O}_{2}$, respectively.

The mathematical model has been carried out through analysis of variance (ANOVA). Only the results for residual acidity showed a lack of significant adjustment. However, in all the experiments, residual acidity contents lower than $2 \%$ were obtained, evidencing the efficiency of the digestion using dilute acid. In general, the model applied was well suited to the obtained values.

\section{Analytical features}

For the proposed method, the following figures of merit were considered: limit of detection (LOD), limit of quantification (LOQ), linearity and accuracy, evaluated under experimental conditions optimized by mixture design.

The linearity for $\mathrm{Cr}, \mathrm{Cu}, \mathrm{Fe}, \mathrm{Mn}$, and $\mathrm{Zn}$ was checked using standard solutions range from 0.1 to $10.0 \mathrm{mg} \mathrm{L}^{-1}$, and for $\mathrm{Ca}, \mathrm{K}, \mathrm{Mg}$, $\mathrm{P}$, and $\mathrm{S}$ was checked using standard solutions range from 0.5 to $80.0 \mathrm{mg} \mathrm{L}^{-1}$. Determination coefficients $\left(\mathrm{R}^{2}\right)$ higher than the minimum value established by INMETRO $^{36}(0.998)$ were obtained. LOD and LOQ obtained for the method proposed are similar to those obtained using microwave-assisted diluted acid digestion for extraction of metals in rice samples, ${ }^{37}$ and microwave-assisted diluted acid digestion for multi-element extraction in guarana samples. ${ }^{38}$ Table 3 summarizes the parameters obtained.

The accuracy of the proposed method was evaluated by the extraction and determination of the studied elements in two certified reference materials (RM-Agro E1001a Brachiaria brizantha cv. Marandu and NIST 1515 apple leaves). Table 3 presents the results for the values determined by ICP OES and the certified values. The unpaired $t$-test demonstrated that there were no significant systematic differences between certified and determined values at $95 \%$ confidence level $(\mathrm{n}=3)$ for $\mathrm{Cr}, \mathrm{Cu}, \mathrm{Fe}, \mathrm{Zn}$, $\mathrm{K}, \mathrm{Mg}, \mathrm{P}$ and $\mathrm{S}$ and at $99 \%$ confidence level for $\mathrm{Ca}$ and $\mathrm{Mn}$.

Table 3. Analytical parameters obtained for the method by ICP OES

\begin{tabular}{|c|c|c|c|c|c|}
\hline Element & $\mathrm{LOD} /\left(\mu \mathrm{g} \mathrm{g}^{-1}\right)$ & $\mathrm{LOQ} /\left(\mu \mathrm{g} \mathrm{g}^{-1}\right)$ & $\begin{array}{l}\text { Certified value / } \\
\left(\mathrm{mg} \mathrm{kg}^{-1}\right)\end{array}$ & $\begin{array}{c}\text { Obtained value } \\
(\text { mean } \pm \mathrm{SD}) /\left(\mathrm{mg} \mathrm{kg}^{-1}\right)\end{array}$ & $\mathrm{R}^{2}$ \\
\hline $\mathrm{Cr}$ & 0.13 & 0.42 & $3.30 \pm 1.66^{\mathrm{a}}$ & $2.69 \pm 0.01$ & 0.9999 \\
\hline $\mathrm{Cu}$ & 0.21 & 0.69 & $4.0 \pm 0.7^{\mathrm{a}}$ & $4.2 \pm 1.5$ & 0.9999 \\
\hline $\mathrm{Fe}$ & 0.45 & 1.5 & $91 \pm 13^{\mathrm{a}}$ & $81 \pm 3.4$ & 0.9998 \\
\hline $\mathrm{Mn}$ & 0.04 & 0.14 & $76.0 \pm 18.5^{\mathrm{a}}$ & $61.9 \pm 2.5$ & 0.9991 \\
\hline $\mathrm{Zn}$ & 0.54 & 1.8 & $9.9 \pm 1.6^{\mathrm{a}}$ & $10.4 \pm 1.5$ & 0.9999 \\
\hline $\mathrm{Ca}$ & 8.70 & 29.0 & $15260 \pm 150^{\mathrm{b}}$ & $16256 \pm 270$ & 0.9990 \\
\hline K & 1.05 & 3.5 & $16100 \pm 200^{\mathrm{b}}$ & $15978 \pm 199$ & 0.9983 \\
\hline $\mathrm{Mg}$ & 0.57 & 1.9 & $2710 \pm 80^{b}$ & $2859 \pm 87$ & 0.9987 \\
\hline $\mathrm{P}$ & 1.92 & 6.4 & $650 \pm 190^{\mathrm{a}}$ & $604 \pm 26.0$ & 0.9998 \\
\hline S & 5.10 & 17 & $1800^{\mathrm{b}}$ & $1821 \pm 102$ & 0.9999 \\
\hline
\end{tabular}

${ }^{a}$ RM-Agro E1001a Brachiaria brizantha cv. Marandu; 'NIST 1515 apple leaves. LOD: limit of detection; LOQ: limit of quantification; SD: standard deviation; $\mathrm{R}^{2}$ : coefficient of determination. 


\section{Application of the method}

After optimization and validation, the method was applied for the quantification of $\mathrm{Cu}, \mathrm{Cr}, \mathrm{Fe}, \mathrm{Zn}, \mathrm{Ca}, \mathrm{K}, \mathrm{Mg}$, $\mathrm{Mn}, \mathrm{P}$ and $\mathrm{S}$ in different fruit tissues of Casearia fasciculata from Lafaiete Coutinho, a municipality in Bahia State. Table 4 shows the results (expressed as mean \pm standard deviation, $\mathrm{n}=3$ ).

In this analysis, three tissues that comprise the fruit (pulp, seed and peel) were considered. It is noted that the lowest mean concentrations were obtained for the pulp; this is mainly due to the amount of water present in the medium. When compared to seed and peel, the elements $\mathrm{Cr}, \mathrm{Fe}, \mathrm{S}$ and $\mathrm{Mg}$ were present in higher amounts in the seed, whereas $\mathrm{Cu}, \mathrm{Mn}, \mathrm{Zn}, \mathrm{Ca}$ and $\mathrm{K}$ were present in higher amounts in the peel. The presence of $\mathrm{Fe}, \mathrm{Ca}$ and $\mathrm{K}$ at considerable concentrations can be related to the regular use of fertilizers from planting to harvest and the presence of soils naturally rich in minerals. The element $\mathrm{P}$ showed concentrations close to both seed and peel. In an increasing order of concentration, the samples had the following classification: $\mathrm{Cr}<\mathrm{Cu}<$

Table 4. Results obtained for fruits of Casearia fasciculata samples by ICP OES ( $\mathrm{n}=3$ )

\begin{tabular}{|c|c|c|c|c|c|c|c|}
\hline \multirow{3}{*}{ Ion } & & \multicolumn{6}{|c|}{ Concentration $($ mean $\pm \mathrm{SD})$} \\
\hline & & \multicolumn{3}{|c|}{ Morro Region } & \multicolumn{3}{|c|}{ Bela Vista Region } \\
\hline & & Collection 1 & Collection 2 & Collection 3 & Collection 1 & Collection 2 & Collection 3 \\
\hline \multirow{3}{*}{$\mathrm{Cr} /\left(\mu \mathrm{g} \mathrm{g}^{-1}\right)$} & pulp & $<\mathrm{LOQ}$ & $<\mathrm{LOQ}$ & $0.866 \pm 0.25$ & $<$ LOQ & $<$ LOQ & $1.52 \pm 0.45$ \\
\hline & seed & $<\mathrm{LOQ}$ & $1.01 \pm 0.29$ & $2.60 \pm 0.38$ & $<\mathrm{LOQ}$ & $2.31 \pm 0.52$ & $3.79 \pm 0.98$ \\
\hline & peel & $<$ LOQ & $0.901 \pm 0.23$ & $1.81 \pm 0.09$ & $<$ LOQ & $<\mathrm{LOQ}$ & $1.11 \pm 0.24$ \\
\hline \multirow{3}{*}{$\mathrm{Cu} /\left(\mu \mathrm{g} \mathrm{g}^{-1}\right)$} & pulp & $2.96 \pm 0.24$ & $4.50 \pm 2.51$ & $3.55 \pm 2.12$ & $1.10 \pm 0.23$ & $1.81 \pm 0.51$ & $3.33 \pm 2.30$ \\
\hline & seed & $13.5 \pm 0.3$ & $20.2 \pm 2.4$ & $15.3 \pm 1.7$ & $15.6 \pm 1.0$ & $19.8 \pm 4.4$ & $17.2 \pm 3.2$ \\
\hline & peel & $7.43 \pm 0.3$ & $25.1 \pm 3.2$ & $59.9 \pm 1.4$ & $6.53 \pm 0.73$ & $31.3 \pm 5.0$ & $31.3 \pm 3.1$ \\
\hline \multirow{3}{*}{$\mathrm{Fe} /\left(\mu \mathrm{g} \mathrm{g}^{-1}\right)$} & pulp & $5.38 \pm 0.16$ & $6.49 \pm 1.33$ & $8.89 \pm 2.86$ & $6.38 \pm 0.40$ & $5.99 \pm 1.16$ & $7.86 \pm 2.92$ \\
\hline & seed & $273 \pm 2$ & $59.8 \pm 8.5$ & $72.9 \pm 9.6$ & $119 \pm 2$ & $82.5 \pm 17.5$ & $76.2 \pm 8.3$ \\
\hline & peel & $38.3 \pm 1.3$ & $77.2 \pm 14.3$ & $96.3 \pm 13.6$ & $34.8 \pm 3.4$ & $74.1 \pm 9.0$ & $80.9 \pm 11.4$ \\
\hline \multirow{3}{*}{$\mathrm{Mn} /\left(\mu \mathrm{g} \mathrm{g}^{-1}\right)$} & pulp & $<\mathrm{LOQ}$ & $<$ LOQ & $<\mathrm{LOQ}$ & $<$ LOQ & $<\mathrm{LOQ}$ & $<$ LOQ \\
\hline & seed & $56.4 \pm 1.3$ & $9.47 \pm 1.75$ & $7.24 \pm 1.30$ & $54.5 \pm 1.0$ & $7.53 \pm 0.50$ & $7.42 \pm 1.45$ \\
\hline & peel & $61.0 \pm 0.6$ & $28.1 \pm 0.5$ & $34.6 \pm 3.3$ & $58.1 \pm 0.8$ & $32.6 \pm 2.1$ & $31.4 \pm 3.6$ \\
\hline \multirow{3}{*}{$\mathrm{Zn} /\left(\mu \mathrm{g} \mathrm{g}^{-1}\right)$} & pulp & $10.2 \pm 0.1$ & $9.00 \pm 0.08$ & $12.9 \pm 1.33$ & $14.6 \pm 4.8$ & $12.2 \pm 1.4$ & $11.7 \pm 2.6$ \\
\hline & seed & $62.3 \pm 14.7$ & $41.6 \pm 5.5$ & $19.9 \pm 4.98$ & $22.7 \pm 7.6$ & $42.2 \pm 1.4$ & $27.1 \pm 0.3$ \\
\hline & peel & $17.1 \pm 1.1$ & $46.6 \pm 6.6$ & $160 \pm 21.74$ & $61.5 \pm 1.4$ & $19.3 \pm 1.0$ & $125 \pm 14$ \\
\hline \multirow{3}{*}{$\mathrm{Ca} /\left(\mathrm{mg} \mathrm{g}^{-1}\right)$} & pulp & $0.852 \pm 0.040$ & $0.449 \pm 0.051$ & $0.325 \pm 0.094$ & $0.784 \pm 0.066$ & $0.277 \pm 0.109$ & $0.283 \pm 0.074$ \\
\hline & seed & $4.21 \pm 0.19$ & $1.64 \pm 0.13$ & $1.46 \pm 0.14$ & $4.59 \pm 0.22$ & $1.46 \pm 0.07$ & $1.41 \pm 0.08$ \\
\hline & peel & $4.94 \pm 0.20$ & $3.64 \pm 0.03$ & $3.81 \pm 0.07$ & $5.20 \pm 0.12$ & $3.76 \pm 0.04$ & $3.61 \pm 0.06$ \\
\hline \multirow{3}{*}{$\mathrm{Mg} /\left(\mathrm{mg} \mathrm{g}^{-1}\right)$} & pulp & $0.685 \pm 0.034$ & $0.871 \pm 0.057$ & $0.779 \pm 0.070$ & $0.727 \pm 0.01$ & $0.805 \pm 0.01$ & $0.755 \pm 0.06$ \\
\hline & seed & $9.63 \pm 1.52$ & $5.43 \pm 0.07$ & $4.87 \pm 0.49$ & $11.5 \pm 0.1$ & $4.87 \pm 0.12$ & $5.06 \pm 0.48$ \\
\hline & peel & $1.68 \pm 0.05$ & $1.31 \pm 0.02$ & $1.36 \pm 0.03$ & $1.58 \pm 0.11$ & $1.31 \pm 0.08$ & $1.32 \pm 0.02$ \\
\hline \multirow{3}{*}{$\mathrm{P} /\left(\mathrm{mg} \mathrm{g}^{-1}\right)$} & pulp & $0.513 \pm 0.015$ & $0.232 \pm 0.034$ & $0.198 \pm 0.029$ & $0.489 \pm 0.011$ & $0.176 \pm 0.026$ & $0.188 \pm 0.019$ \\
\hline & seed & $2.76 \pm 0.45$ & $1.11 \pm 0.02$ & $1.00 \pm 0.09$ & $3.13 \pm 0.06$ & $1.02 \pm 0.01$ & $1.04 \pm 0.07$ \\
\hline & peel & $2.27 \pm 0.12$ & $1.34 \pm 0.02$ & $1.39 \pm 0.04$ & $2.30 \pm 0.06$ & $1.38 \pm 0.07$ & $1.35 \pm 0.03$ \\
\hline \multirow{3}{*}{$\mathrm{S} /\left(\mathrm{mg} \mathrm{g}^{-1}\right)$} & pulp & $0.295 \pm 0.013$ & $0.160 \pm 0.016$ & $0.126 \pm 0.021$ & $0.283 \pm 0.010$ & $0.140 \pm 0.016$ & $0.137 \pm 0.023$ \\
\hline & seed & $2.77 \pm 0.50$ & $1.16 \pm 0.01$ & $1.05 \pm 0.10$ & $3.11 \pm 0.01$ & $1.07 \pm 0.02$ & $1.09 \pm 0.10$ \\
\hline & peel & $1.49 \pm 0.05$ & $0.768 \pm 0.013$ & $0.789 \pm 0.018$ & $1.49 \pm 0.06$ & $0.789 \pm 0.04$ & $0.784 \pm 0.01$ \\
\hline \multirow{3}{*}{$\mathrm{K} /\left(\mathrm{mg} \mathrm{g}^{-1}\right)$} & pulp & $1.88 \pm 0.03$ & $1.20 \pm 0.02$ & $1.04 \pm 0.05$ & $1.84 \pm 0.01$ & $1.17 \pm 0.05$ & $1.09 \pm 0.14$ \\
\hline & seed & $11.9 \pm 0.06$ & $3.64 \pm 0.21$ & $1.13 \pm 0.18$ & $11.7 \pm 0.56$ & $2.14 \pm 1.18$ & $1.55 \pm 0.21$ \\
\hline & peel & $17.2 \pm 0.31$ & $5.12 \pm 0.60$ & $5.41 \pm 0.16$ & $17.6 \pm 0.38$ & $12.7 \pm 1.15$ & $6.22 \pm 0.26$ \\
\hline
\end{tabular}

SD: standard deviation; LOQ: limit of quantification $\left(\mathrm{Cr}=0.42 \mu \mathrm{g} \mathrm{g}^{-1}\right.$ and $\left.\mathrm{Mn}=0.14 \mu \mathrm{g} \mathrm{g}^{-1}\right)$. 
$\mathrm{Mn}<\mathrm{Zn}<\mathrm{Fe}$ (micronutrients) and $\mathrm{S}<\mathrm{P}<\mathrm{Ca}<\mathrm{Mg}<$ $\mathrm{K}$ (macronutrients).

Regarding the collection period, most of the samples collected in 2016 had higher concentrations than those collected in 2018 and 2019. The difference in the concentrations between the years of collection may be related to factors such as cation exchange capacity of soil, soil $\mathrm{pH}$, climatic conditions, fertilizer application, among others. ${ }^{39}$

In relation to the collection region, the samples collected in Morro presented concentrations similar to those collected in Bela Vista. The individual results of the concentrations for macro- and micronutrients can be observed in the Supplementary Information section (Figures S1 and S2), respectively.

The elements determined in this study show great biological importance against several diseases, since they play an essential role in the activity of practically all enzymes, either as cofactors or in the active site of the enzyme, and the intake of each element in tolerable amounts is recommended..$^{17,40,41}$ Therefore, the knowledge of mineral contents in food matrices such as regional fruits is essential, as it provides information on nutritional and toxicological aspects.

\section{Exploratory analysis}

Multivariate analysis by PCA and HCA was performed on a self-scaled matrix (centered on the mean and scaled by the single variance) of 54 samples of the fruit (pulp 1-18, seed 19-36 and peel 37-54) and 10 variables $(\mathrm{Ca}, \mathrm{Cr}, \mathrm{Cu}$, $\mathrm{Fe}, \mathrm{K}, \mathrm{Mg}, \mathrm{Mn}, \mathrm{P}, \mathrm{S}$ and $\mathrm{Zn}$ ). PCA and HCA are techniques widely used in the search for behavior patterns. ${ }^{42,43}$

In order to evaluate the feasibility of the factorial analysis from a correlation matrix of the data set, in the Kaiser-Meyer-Olkin test the found value of 0.729 was higher than the established value of 0.60 . The Bartlet sphericity test and the chi-square value of 1049.7 showed the significance of the correlations at $p<0.001$, which is considered acceptable.

After adequacy of the matrix, the analysis of factors by the main component method applied generated ten orthogonal vectors (PCs). The first three components had eigenvalues $5.59 ; 1.95 ; 1.54$ and total variances of 55.9 ; $19.5 ; 15.4 \%$, respectively. The sum of variances explained $90.8 \%$ of the information from the original data, and the Kaiser rule (number of eigenvalues $>1$ ) was considered for the study.

In Figure 3 the linear combinations of the three vectors (PC1, PC2 and PC3) relating loadings and variables will be considered in the PCA description:

$$
\begin{aligned}
& \mathrm{PC} 1=0.165 \mathrm{Cr}-0.392 \mathrm{Cu}-0.786 \mathrm{Fe}-0.941 \mathrm{Mn}- \\
& 0.431 \mathrm{Zn}-0.917 \mathrm{Ca}-0.660 \mathrm{Mg}-0.982 \mathrm{P}-0.904 \mathrm{~S}- \\
& 0.814 \mathrm{~K}
\end{aligned}
$$

$\mathrm{PC} 2=0.695 \mathrm{Cr}+0.828 \mathrm{Cu}+0.223 \mathrm{Fe}-0.129 \mathrm{Mn}+$
$0.745 \mathrm{Zn}+0.00323 \mathrm{Ca}-0.0735 \mathrm{Mg}-0.132 \mathrm{P}-$
$0.150 \mathrm{~S}-0.336 \mathrm{~K}$

$\mathrm{PC} 3=-0.430 \mathrm{Cr}+0.222 \mathrm{Cu}-0.414 \mathrm{Fe}+0.267 \mathrm{Mn}+$

$0.341 \mathrm{Zn}+0.353 \mathrm{Ca}-0.718 \mathrm{Mg}-0.0562 \mathrm{P}$

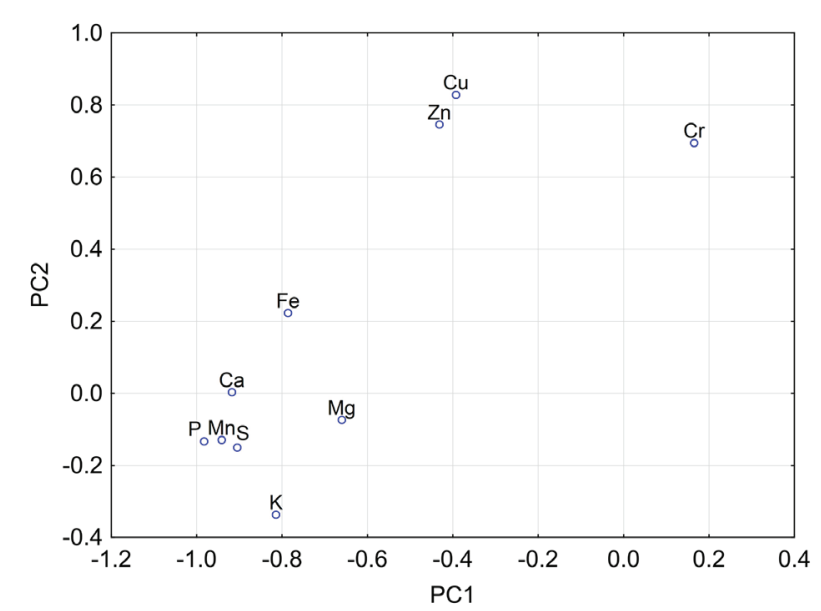

Figure 3. PCA loadings plot for mineral content in the Casearia fasciculata samples.

The calculated results suggest that, in PC1, iron, manganese, calcium, phosphorus, sulfur and potassium have negative values of high correlations, while in PC2, chromium, copper and zinc presented positive values. In particular, magnesium has an expressive contribution in the last PC (PC3). Evidently, $\mathrm{PC} 1$ is generally more correlated with variables than $\mathrm{PC} 2$.

The inspection of Figure 4 shows the tendency of formation of 3 groups according to the parts of the fruit: pulp, seed and peel. An ellipse (blue line) at $95 \%$ confidence interval was applied in PCA score plot. Although presenting different concentrations in relation to the parts of the fruit, samples were within the $95 \%$ confidence limit. The samples $(19,20,21,28,29$ and 30) projected in the third quadrant belong to the same group of seed samples located in the opposite quadrant, but present different behaviors with high negative correlation values for $\mathrm{P}, \mathrm{Mn}, \mathrm{Ca}$ and $\mathrm{S}$, indicating high concentrations of these elements. This suggests that this separation may be associated to the nature of soil used in planting. On the other hand, still in this same position of the first quadrant, the other samples show only expressive value of $\mathrm{Cr}$.

The displacement of the samples considered as outliers (Pe43 and Pe45), as well as the sample Pe44, 


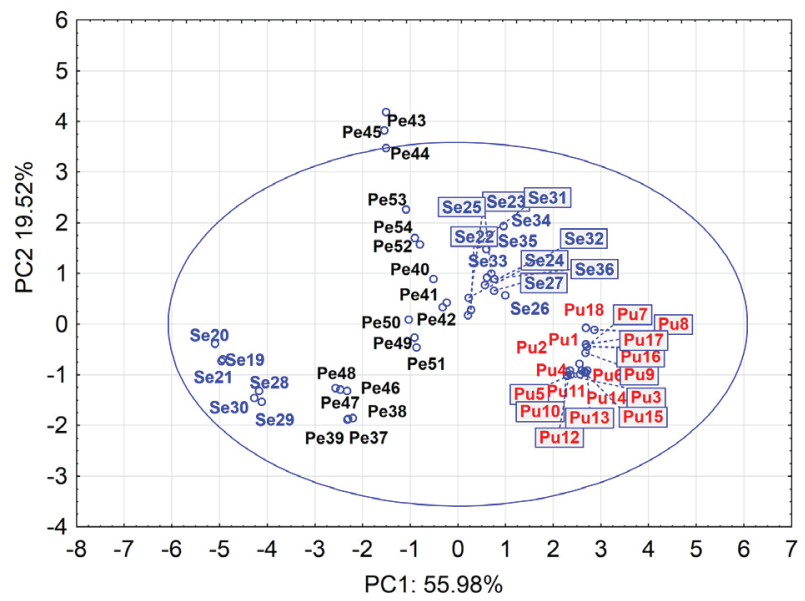

Figure 4. PCA scores plot for mineral content in the Casearia fasciculata samples.

occurred because these samples presented the highest concentrations for $\mathrm{Cr}, \mathrm{Cu}, \mathrm{Fe}$ and $\mathrm{Zn}$ elements and the lowest concentration for $\mathrm{K}$ element. For $\mathrm{Ca}, \mathrm{Mg}, \mathrm{P}$ and $\mathrm{S}$ elements the concentrations were equivalent to the other samples.

With respect to the peel samples projected from the left side, the strong association with $\mathrm{Ca}, \mathrm{Fe}, \mathrm{P}, \mathrm{Mn}, \mathrm{K}$ and $\mathrm{Mg}$ in $\mathrm{PC} 1$, as well as $\mathrm{Cu}$ and $\mathrm{Zn}$ elements in $\mathrm{PC} 2$, is perceptible. This shows a strong absorption of these elements by fruit peels compared to the pulps distributed in the fourth quadrant with low concentrations of all elements, except for the same contribution of chromium observed in the seeds.

It was not presented in this work the projection of the samples to the orthogonal vectors (PC1 $\times$ PC 3 ), but it is verified by the $\mathrm{PC} 3$ and $\mathrm{PC} 1$ equations little differentiated contributions in the Mn loadings, so it was considered already evaluated.

Table 5 shows the correlation matrix of the variables $(p<0.05)$. The eigenvalues in PCA equal the eigenvalues of the Pearson correlation matrix of the variables and represent the variance accounted by the principal components. ${ }^{44} \mathrm{We}$ can highlight strong and positive correlations such as: phosphorus and sulfur $(r=0.938)$, calcium and potassium $(r=0.904)$, calcium and manganese $(r=0.971)$, manganese and phosphorus $(r=0.934)$, and manganese and potassium $(\mathrm{r}=0.934)$. The low correlations found for $\mathrm{Cr}$ and $\mathrm{Cu}$ are probably due to the small concentrations obtained in the samples.

The trends of correlations observed through the PCs were confirmed from the dendogram obtained by HCA (Figure 5). In this study, the data set was treated by Euclidian distance and complete linkage.

Considering Figure 5a, it can be observed different groups separated by similarity with normalized Euclidean distance of $60 \%$. The first group on the right corresponds formation of 2 subgroups (pulp samples: Pu1-Pu18 and seed samples: Se22-Se27; Se31-Se36) due to the small similarities in mineral composition. The samples of peel (Pe37-Pe54) on the left are part of a second group with similar characteristics, but some seed samples (Se19-Se21; Se28-Se30) are mixed with this group, which may be associated to the different type of soil already mentioned in PCA and by the high concentrations of $\mathrm{Ca}, \mathrm{P}, \mathrm{Mn}$ and $\mathrm{S}$ that are also present in the peels.

Figure $5 \mathrm{~b}$ presents the hierarchical dendrogram showing the similarity between the chemical variables. In this figure is observed the presence of one cluster consisting of the elements $\mathrm{Cr}, \mathrm{Cu}, \mathrm{Mn}, \mathrm{Zn}$ and $\mathrm{Fe}$, a second cluster consisting of the elements $\mathrm{P}$ and $\mathrm{S}$ and finally a third cluster corresponded to the elements $\mathrm{K}, \mathrm{Mg}$ and $\mathrm{Ca}$.

\section{Conclusions}

Our study is the first to propose the simultaneous quantification of 10 elements in fruits of Casearia fasciculata

Table 5. Correlation matrix for the studied chemical variables

\begin{tabular}{|c|c|c|c|c|c|c|c|c|c|c|}
\hline & $\mathrm{Cr}$ & $\mathrm{Cu}$ & $\mathrm{Fe}$ & $\mathrm{Mn}$ & $\mathrm{Zn}$ & $\mathrm{Ca}$ & $\mathrm{Mg}$ & $\mathrm{P}$ & $S$ & $\mathrm{~K}$ \\
\hline $\mathrm{Cr}$ & 1.000 & & & & & & & & & \\
\hline $\mathrm{Cu}$ & 0.345 & 1.000 & & & & & & & & \\
\hline $\mathrm{Fe}$ & 0.084 & 0.403 & 1.000 & & & & & & & \\
\hline Mn & -0.294 & 0.300 & 0.579 & 1.000 & & & & & & \\
\hline $\mathrm{Zn}$ & 0.193 & 0.799 & 0.392 & 0.383 & 1.000 & & & & & \\
\hline $\mathrm{Ca}$ & -0.227 & 0.437 & 0.544 & 0.971 & 0.475 & 1.000 & & & & \\
\hline $\mathrm{Mg}$ & 0.084 & 0.069 & 0.770 & 0.421 & 0.013 & 0.334 & 1.000 & & & \\
\hline $\mathrm{P}$ & -0.195 & 0.254 & 0.730 & 0.934 & 0.300 & 0.894 & 0.699 & 1.000 & & \\
\hline$S$ & -0.089 & 0.142 & 0.807 & 0.768 & 0.162 & 0.692 & 0.898 & 0.938 & 1.000 & \\
\hline K & -0.423 & 0.117 & 0.369 & 0.934 & 0.181 & 0.904 & 0.256 & 0.826 & 0.631 & 1.000 \\
\hline
\end{tabular}



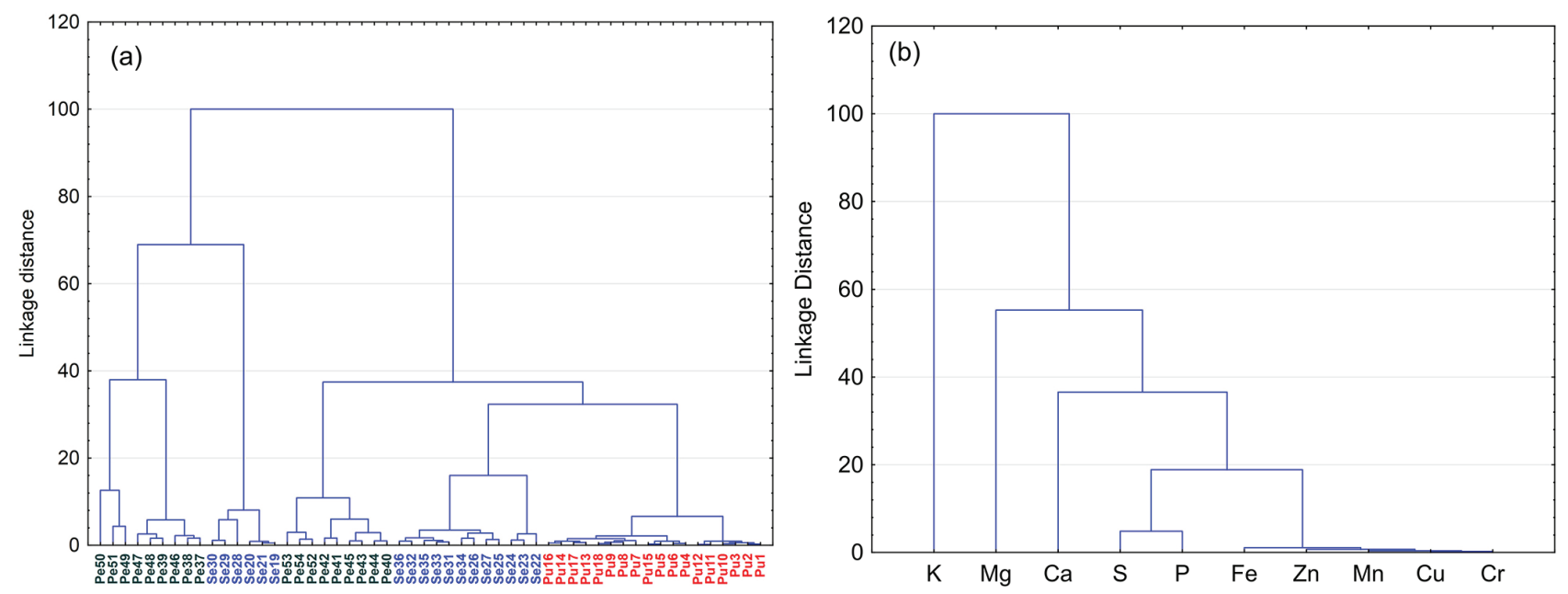

Figure 5. Multivariate analysis of mineral content in the Casearia fasciculata samples using complete linkage with Euclidean distances: dendrogram (a) of the samples and (b) of the variables.

by ICP OES. The digestion with diluted nitric acid and hydrogen peroxide proved to be an efficient alternative for sample preparation of food matrices. In addition, interesting results were obtained for linearity, LOD, LOQ and accuracy.

Mixture design provided quickness and efficiency in the optimization of the digestion method. The application of the two multi-responses functions (multiple response and desirability) was useful for optimizing the proportions of the reagents used in digestion for all elements simultaneously. The method also provided low residual carbon content and low residual acidity.

The chemometric tools (PCA and HCA) applied for information processing obtained by ICP OES contributed effectively and quickly to data analysis and interpretation. Such techniques classified the different tissues of fruits into well defined groups based on the mineral concentration of the ten analytes. In addition, the peel and seed of Casearia fasciculata presents potential to be used as mineral supplements in human nutrition.

\section{Supplementary Information}

Supplementary data (graphs of the concentration of micro and macronutrients) are available free of charge at http://jbcs.sbq.org.br as PDF file.

\section{Acknowledgments}

This study was financed in part by the Coordenação de Aperfeiçoamento de Pessoal de Nível Superior, Brazil (CAPES), Finance Code 001, and Conselho Nacional de Desenvolvimento Científico e Tecnológico (CNPq, process 431491/2016-0).

\section{Author Contributions}

Ivana L. S. Romão is the main author of the work, developed during her doctorate. She collected the plant material and performed the digestion process of the samples. She also made the experiments of mixture design, as well as all the processing of data obtained by ICP OES; Franciele C. Novais participated in the process of digestion of samples of Casearia fasciculata, identified the possibility of studying 4 different responses applying mixture design, set up the experimental matrix for the application of mixture design, as well as following the experiments; Rosivan S. Assis followed the process of collection of plant material for later identification of the specie, as well as doing the exsiccates, and processed the data obtained in the mixture design using the Statistica software; Vinnícius H. C. da Silva performed the method validation process using the ICP OES technique, as well as performed all spectral analysis; Raildo M. de Jesus developed a specific method for the determination of inorganic constituents in Casearia fasciculata fruit using the ICP OES technique; Cleber G. Novaes is the co-advisor of the doctoral student Ivana Romão (main author). He followed all stages of the work, as well as organized the data for submission in JBCS; Ana M. P. dos Santos is the advisor of the doctoral student Ivana Romão (main author). She followed all the steps of the work, and performed the statistical treatment by PCA and HCA analysis.

\section{References}

1. Núcleo de Estudos e Pesquisas em Alimentação (NEPA); Tabela Brasileira de Composição de Alimentos (TACO), $4^{\text {th }}$ ed., revised and expanded; NEPA/UNICAMP: Campinas, Brazil, 2011. 
2. Anhesine, N. B.; Bueno, P. C. P.; Torres, R. B.; Lopes, N. P.; Cavalheiro, A. J.; Biochem. Syst. Ecol. 2019, 87, 103954.

3. Lorenzi, H.; Souza,V. C.; Botânica Sistemática: Guia Ilustrado para Identificação das Famílias de Angiospermas da Flora Brasileira, Baseado em APG II; Instituto Plantarum: Nova Odessa, SP, Brazil, 2005.

4. Ferreira, P. M. P.; Costa-Lotufo, L. V.; Moraes, M. O.; Barros, F. W. A.; Martins, A. M. A.; Cavalheiro, A. J.; Bolzani, V. S.; Santos, A. G.; Pessoa, C.; An. Acad. Bras. Cienc. 2011, 83, 1373.

5. Ruppelt, B. M.; Pereira, E. F. R.; Gonçalves, L. C.; Pereira, N. A.; Mem. Inst. Oswaldo Cruz 1991, 86, 203.

6. Żyrnicki, W.; Borkowska-Burnecka, J.; Leśniewicz, A. In Handbook of Trace Analysis; Baranowska, I., ed.; Springer: Cham, 2016, p. 123.

7. Bezerra, M. A.; Ferreira, S. L. C.; Novaes, C. G.; dos Santos, A. M. P.; Valasques, G. S.; Cerqueira, U. M. F. M.; Alves, J. P. S.; Microchem. J. 2016, 128, 331.

8. Bezerra, M. A.; Ferreira, S. L. C.; Novaes, C. G.; dos Santos, A. M. P.; Valasques, G. S.; Cerqueira, U. M. F. M.; Alves, J. P. S.; Talanta 2019, 194, 941.

9. Korn, M. G. A.; Morte, E. S. B.; Santos, D. C. M. B.; Castro, J. T.; Barbosa, J. T. P.; Teixeira, A. P.; Fernandes, A. P.; Welz, B.; Santos, W. P. C.; Santos, E. B. G. N.; Korn, M.; Appl. Spectrosc. Rev. 2008, 43, 67.

10. Flores, E. M. M.; Microwave-Assisted Sample Preparation for Trace Element Determination, $1^{\text {st }}$ ed.; Elsevier: Amsterdam, 2014.

11. Krug, F. J.; Rocha, F. R. P.; Métodos de Preparo de Amostras para Análise Elementar; EditSBQ: São Paulo, Brazil, 2016.

12. Bizzi, C. A.; Nóbrega, J. A.; Barin, J. S. In Microwave-Assisted Sample Preparation for Trace Element Analysis, $1^{\text {st }}$ ed.; Flores, E. M. M., ed.; Elsevier: Amsterdam, 2014, p. 179.

13. Souza, L. A.; Souza, T. L.; Santana, F. B.; Araujo, R. G. O.; Teixeira, L. S. G.; Santos, D. C. M. B.; Korn, M. G. A.; Microchem. J. 2018, 137, 8.

14. Tarantino, T. B.; Barbosa, I. S.; Lima, D. C.; Pereira, M. G.; Teixeira, L. S. G.; Korn, M. G. A.; Food Anal. Methods 2017, $10,1007$.

15. Costa, V. C.; Guedes, W. N.; Santos, A. S.; Nascimento, M. M.; Food Anal. Methods 2018, 11, 2004.

16. Novaes, C. G.; Romão, I. L. S.; Santos, B. G.; Ribeiro, J. P.; Bezerra, M. A.; da Silva, E. G. P.; Food Chem. 2017, 233, 507.

17. Pereira, R. M.; Crizel, M. G.; Novo, D. L. R.; dos Santos, C. M. M.; Mesko, M. F.; Microchem. J. 2019, 145, 235.

18. Barbosa, J. T. P.; Santos, C. M. M.; Peralva, V. N.; Flores, E. M. M.; Korn, M.; Nobrega, J. A.; Korn, M. G. A.; Food Chem. 2015, 175, 212.

19. Bizzi, C. A.; Barin, J. S.; Garcia, E. E.; Nóbrega, J. A.; Dressler, V. L.; Flores, E. M. M.; Spectrochim. Acta, Part B 2011, 66, 394.

20. Todolí, J. L.; Mermet, J. M.; Spectrochim. Acta, Part B 1999 , 54,895 .
21. Cruz, S. M.; Schmidt, L.; Nora, F. M. D.; Pedrotti, M. F.; Bizzi, C. A.; Barin, J. S.; Flores, E. M. M.; Microchem. J. 2015, 123, 28.

22. Costa, V. C.; Silva, E. G. P.; Lima, D. C.; Franco, M.; Jesus, R. M.; Bezerra, M. A.; Amorim, F. A. C.; J. Braz. Chem. Soc. 2018, 29, 1189 .

23. Sanchez, P. M.; Pauli, E. D.; Scheel, G. L.; Rakocevic, M.; Bruns, R. E.; Scarminio, I. S.; J. Braz. Chem. Soc. 2018, 29, 168.

24. Novaes, C. G.; Yamaki, R. T.; de Paula, V. F.; do Nascimento Junior, B. B.; Barreto, J. A.; Valasques, G. S.; Bezerra, M. A.; Rev. Virtual Quim. 2018, 10, 393.

25. Valasques, G. S.; dos Santos, A. M. P.; da Silva, D. G.; Alves, J. P. S.; Bezerra, M. A.; J. Braz. Chem. Soc. 2018, 29, 2189.

26. Statistica, version 12; StatSoft, Inc., Tulsa, OK, USA, 2013.

27. IBM SPSS Statistics for Windows, version 24.0; IBM Corp., Armonk, New York, USA, 2016.

28. Barros Neto, B.; Scarmínio, I. S.; Bruns, R. E.; Como Fazer Experimentos: Aplicações na Ciência e na Indústria, $4^{\text {th }}$ ed.; Bookman: Porto Alegre, Brazil, 2010.

29. Ferreira, S. L. C.; Introdução às Técnicas de Planejamento de Experimentos, $1^{\text {st }}$ ed.; Editora Vento Leste: Salvador, Brazil, 2015.

30. Bhandari, S. A.; Amarasiriwardena, D.; Microchem. J. 2000, $64,73$.

31. Barbosa, I. S.; Brito, G. B.; Santos, G. L.; Santos, L. N.; Teixeira, L. S. G.; Araujo, R. G. O.; Korn, M. G. A.; Food Chem. 2019, 273, 64 .

32. Barela, P. S.; Silva, N. A.; Pereira, J. S. F.; Marques, J. C.; Rodrigues, L. F.; Moraes, D. P.; Fuel 2017, 204, 85.

33. Muller, A. L. H.; Muller, E. I.; Barin, J. S.; Flores, E. M. M.; Anal. Methods 2015, 7, 5218.

34. Mullapudi, V. B. K.; Chandrasekaran, K.; Venkateswarlu, G.; Karunasagar, D.; Microchem. J. 2019, 146, 807.

35. Lemos, V. A.; Novaes, C. G.; Bezerra, M. A.; J. Food Compos. Anal. 2009, 22, 337.

36. Instituto Nacional de Metrologia, Normalização e Qualidade Industrial (INMETRO); DOQCGCRE-008, Orientação Sobre Validação de Métodos Analíticos; INMETRO: Rio de Janeiro, Brazil, 2011. Available at http://www.inmetro.gov.br/Sidoq/ Arquivos/CGCRE/DOQ/DOQ-CGCRE-8_04.pdf, accessed in December 2019.

37. da Silva, I. J. S.; Paim, A. P. S.; da Silva, M. J.; Microchem. J. 2018, 137, 131.

38. Santos, H. M.; Coutinho, J. P.; Amorim, F. A. C.; Lôbo, I. P.; Moreira, L. S.; Nascimento, M. M.; de Jesus, R. M.; Food Chem. 2019, 273, 159.

39. Bravo, S.; Amorós, J. A.; Pérez-de-los-Reyes, C.; García, F. J.; Moreno, M. M.; Sánchez-Ormeño, M.; Higueras, P.; J. Geochem. Explor. 2017, 174, 79.

40. Smichowski, P.; Londonio, A.; Microchem. J. 2018, 136, 113. 41. Hu, J.; Yang, P.; Hou, X.; Appl. Spectrosc. Rev. 2019, 54, 180. 
42. Correia, P. R. M.; Ferreira, M. M. C.; Quim. Nova 2007, 30, 481.

43. Jolliffe, I. T.; Cadima, J.; Phil. Trans. R. Soc., A 2016, 374, DOI 10.1098/rsta.2015.0202.
44. Linting, M.; Os, B. J. V.; Meulman, J. J.; Psychometrika 2011, 76,440 .

Submitted: September 30, 2019

Published online: January 7, 2020 